GIS - 理論と応用

Theory and Applications of GIS, 2007, Vol. 15, No.2, pp.55-62

【原著論文】

\title{
ネットワークボロノイクロス K関数法の提案とそのツール開発
}

\section{佐藤俊明・岡部篤行}

\section{Development of a tool for network Voronoi cross $\mathrm{K}$ function methods}

\author{
Toshiaki SATOH and Atsuyuki OKABE
}

\begin{abstract}
The purposes of this paper are: to propose the network Voronoi cross $\mathrm{K}$ function (NVCKF) methods which analyze the distribution of points in relations to points, lines and polygons on network Voronoi areas; and to develop a GIS-based tool for performing these methods. First, the paper explains the planar Voronoi cross K function (PVCKF) method which analyzes the points in relations to points on planar Voronoi areas. Second, the paper formulates the point NVCKF method and the line NVCFK method by extending the PVCKF method to a network. Third, the paper implements these computation methods as a GIS-based tool. Last, the paper tests applicability of the proposed methods to actual data analysis using the tool.
\end{abstract}

Keywords: ボロノイクロスK関数法（Voronoi cross K function method），点ネットワークボロノイ 図（point network Voronoi diagram），線ネットワークボロノイ図 (line network Voronoi diagram), 二項検定 (binominal test)

\section{1.はじめに}

都市䇥間における様々な地物や現象は相互に影響 を受けながら存在もしくは発生している。 中でも， 駅や主要道路といった長期的に変わらない基盤的な 施設（以降，基盤と呼ぶ）は，コンビニエンススト アや交通事故などのように短期的に盛衰する施設や 現象 (以降, 活動点と呼ぶ) の分布に強く影響を与 える可能性がある。そのため, 基盤が活動点の分布 にどのように影響を及ぼしいるかを計量的に調べ ることは，空間解析においては重要な課題であり， これまでもいくつかの解析手法が開発されてきた. 例えば，条件付最近隣法（Okabe and Miki, 1984）や クロス K 関数法 (Ripley, 1981) などである.

佐藤： T 153-0043 東京都目黑区東山 2-8-10 目黑ビル 別館 株式会社パスコ Tel : 03-3715-4011

E-mial : toshiaki_satpi@pasco.co.jp
条件付最近隣法は，基盤と活動点の分布関係の平 均的な近接傾向を示すもので，大まかな分布関倸を 把握するには便利な手法である。しかし，基盤から どれぐらいの距離にどのような分布傾向があるかを 知ることはできない．このようなことは，最近隣距 離法 (Clark and Evans, 1954) などでも同様な問題が あり、これに対してRipley（1981）は，この問題点 を取り除いた K関数法を開発した.この $\mathrm{K}$ 関数法は, 同種類の地物の分布性状を把握するもので，基盤に 対する活動点の分布性状を把握するには，クロス $\mathrm{K}$ 関数法が用いられる。

しかし，このクロス $\mathrm{K}$ 関数法も遠方の影響を大 きく受ける可能性があることが Okabe et al. (2006) によって指摘されている，地物によっては，最寄り の基盤を強く意識して，立地もしくは発生している ものもあると考える。例えば，ひったくり犯罪は 主要幹線道路近辺に多〈発生しているという報告 ${ }^{1)}$ 
や，犯罪発生率は全般的に主要幹線道路に近いほど 高くなっているという報告（江口・有馬，2004）が ある。これらにより，犯罪地点が最寄りの基盤であ る主要幹線道路の影響を大きく受けている可能性が 考えられる.

そこで Okabe et al. (2006) は，平面空間上のクロ ス $\mathrm{K}$ 関数法の遠方の影響を取り除くボロノイクロ ス K 関数法（VCKF 法）を提案している。この手法 は，平面空間上の基盤を母点としたボロノイ図を生 成し，その領域内で，直線距離を用いることによる 母点と活動点の分布性状を把握するものである.

ところで，都市空間においては，人や物の移動 は道路網に規定されている，そのため上記の VCKF 法のように直線距離ではなく，道路に沿った経路距 離を用いたほうが，より現実に即した解析が可能と なる場合があるであろう。

そこで本論文では，VCKF 法をネットワーク空間 へ拡張するネットワーク VCKF 法 (以降, NVCKF 法) の提案とそのッールの開発を行うこととする

第 2 節で既往の手法であるVCKF 法に関して説 明し，第 3 節では基盤の幾何学的形状の違いによる NVCKF 法を定義する．第 4 節では本論文の手法の プログラムに関する概要を説明し，第 5 節では，本 ツールによる解析事例を挙げる，最後に第 6 節とし てまとめを述べる。

\section{2. 平面空間上の VCKF 法}

平面空間上の VCKF 法は，解析領域内の点密度 を $\rho$ (単位：点数 /面積)，各母点加らの直線距離

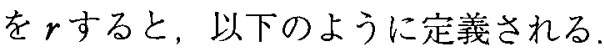

$$
K_{\mathrm{vc}}(r)=\frac{\left[\begin{array}{l}
\text { 基盤を生成元としたボロノイ領 } \\
\text { 域内にあり, 同時に基盤を中心 } \\
\text { に半径 } r \text { 内にある活動点の個数 }
\end{array}\right]}{\rho}
$$

また, $\mathrm{VCKF}$ 法の期待値 $\bar{K}_{\mathrm{vc}}(r)$ は以下の式で与え られる。

$$
\bar{K}_{\mathrm{vc}}(r)=\left[\begin{array}{l}
\text { 各基盤からの半径 } r \text { の円とボロ } \\
\text { イイ領域で切り取られる面積 }
\end{array}\right]
$$

クロス $\mathrm{K}$ 関数法と $\mathrm{VCKF}$ 法との違いは，クロス $\mathrm{K}$ 関数法がそれぞれの基盤から最遠方の活動点まで

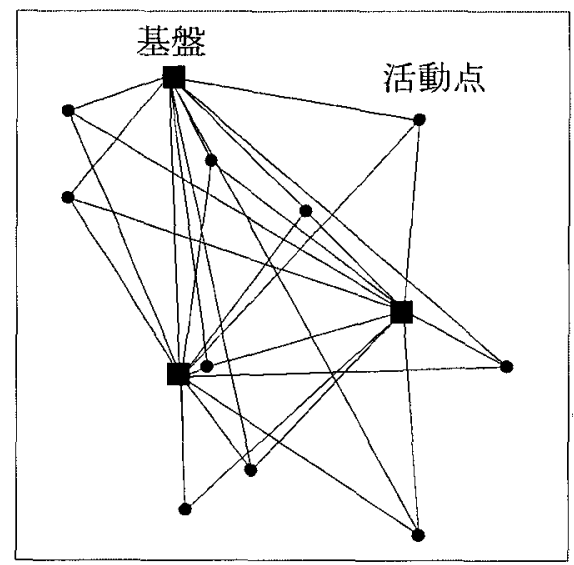

(a)クロス $\mathrm{K}$ 関数法

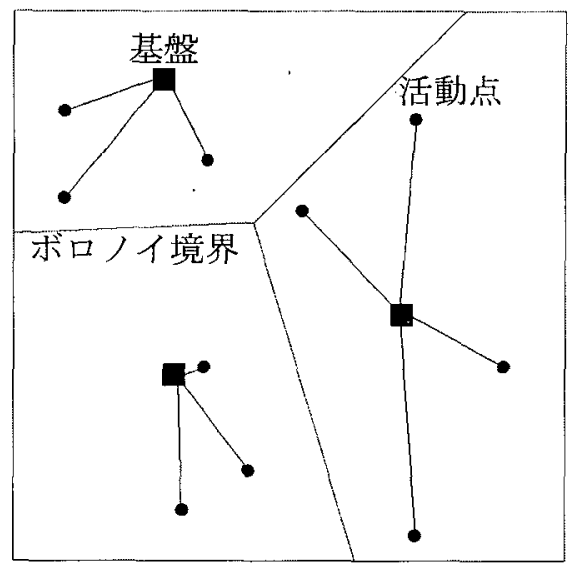

(b) VCKF 法

図 1 クロス K 関数法と VCKF 法との違い

考慮するのに対して（図 1-（a)），VCKF 法では基盤 からボロノイ領域内の活動点だけを対象とすること にある（図 1- (b))。このため VCKF 法の解析結果 には遠方の影響が含まれず，最近隣点の遠近を評価 するものとなる。なお，クロス $\mathrm{K}$ 関数法では活動 点を重複してカウントするため，最後に基盤の個数 で平均を取る必要があるが、VCKF 法ではその必要 がない.

\section{3. 生成元の幾何学的形状の違いによる NVCKF法の定军}

本節では，平面空間上の VCKF 法をネットワー ク空間上に拡張する，基本的な考え方は，ボロノ イ図の代わりにネットワークボロノイ図（以降， NVD）を用いて，そのボロノイ領域内での分布性状 を把握するものである。なお NVD は，基盤の幾何 学的形状により点, 線, 面の三つに分類される。こ 
のうち面 NVD は，線 $\mathrm{NVD}^{2)}$ と同様に考えられるこ とから（佐藤・岡部，2006b），ここでは，点 NVD と線 NVDの場合について定義を行う.

\section{1. 点を生成元とする NVCKF 法}

点的基盤を母点とみなす点 NVCKF 法は，解析領 域内の点密度を $\omega$ (単位：点数／長さ), 各母点か らの最短経路距離を $\boldsymbol{d}$ とすると，以下のように定義 される。

$$
K_{\mathrm{PNVC}}(d)=\frac{\left[\begin{array}{l}
\text { 点的基盤を生成元とした点ネットワーク } \\
\text { ボロノイ領域内にあり, 同時に, その } \\
\text { 基盤から圈域 } d \text { 内にある活動点の個数 }
\end{array}\right]}{\omega}
$$

$\mathrm{NVCKF}$ 法の期待値 $\bar{K}_{\mathrm{PNVC}}(d)$ は以下の式で与えら れる。

$$
\bar{K}_{\mathrm{PNVC}}(d)=\left[\begin{array}{l}
\text { 各基盤からのボロノイ領域内 } \\
\text { で, 基盤から圈域 } d \text { 内にある } \\
\text { ネットワーク長 }
\end{array}\right]
$$

また，解析対象の総延長が $L_{\mathrm{T}}$ のネットワークに 対して, 点的基盤からの経路距離 $d$ 内に活動点が多 く存在するのか，少なく存在するのかをみる統計的 検定には，次に示す経路距離 $d$ における二項分布を 用いた二項検定を行えばよい。ここで $n$ は活動点 の数を, $k$ は 1 から $n$ までの整数を示す.

$$
\begin{aligned}
& P_{\mathrm{PNVC}}(k \mid d) \\
& { }_{{ }_{n}} C_{k}\left(\frac{\bar{K}_{\mathrm{PNVC}}(d)}{L_{\mathrm{T}}}\right)^{n-k}\left(\frac{L_{\mathrm{T}}-\bar{K}_{\mathrm{PNVC}}(d)}{L_{\mathrm{T}}}\right)^{k}
\end{aligned}
$$

\section{2. 線および面を生成元とする NVCKF 法}

線的基盤を母線とみなす線 NVCKF 法は以下のよ うに定義される.

$$
K_{\mathrm{LNVC}}(d)=\frac{\left[\begin{array}{l}
\text { 線的基盤を生成元とした線ネットワーク } \\
\text { ボロノイ領域にあり, 同時に, その基盤 } \\
\text { から圈域 } d \text { 内にある活動点の個数 }
\end{array}\right]}{\omega}
$$

線的基盤の総延長を $L_{\mathrm{TB}} \neq 0$ すると NVCKF 法の 期待値 $\bar{K}_{\mathrm{LNVC}}(d)$ は以下の式で与えられる.
$\bar{K}_{\mathrm{LNVC}}(d)=L_{\mathrm{TB}}+\left[\begin{array}{l}\text { 線的基盤を除く各線的基盤からの } \\ \text { ボロノイ領域内で, 線的基盤から } \\ \text { 圈域 } \boldsymbol{d} \text { 内にあるネットワ長 }\end{array}\right]$

この式が示すとおり, 点 NVCKF 法と異なる点は, $d=0$ においても期待值が $\bar{K}_{\mathrm{LNVC}}(d)=L_{\mathrm{TB}}$ となり， 0 にならない点である。

また，統計的検定は (1) 式の $\bar{K}_{\mathrm{PNVC}}(d)$ を $\bar{K}_{\mathrm{LNVC}}(d)$ に代えて用いればよい.

\section{3. NVCKF 法のグラフ}

$\mathrm{NVCKF}$ 法は, クロス $\mathrm{K}$ 関数法と同様に, 図 2 の ような母点（線 NVCKF 法の場合は母線. 以下は点 NVCKF 法に関して記述する）からの圈域 $d$ を横軸 に, $\bar{K}_{\mathrm{PNVC}}(d)$ を縦軸にとり，期待值曲線(図 2 の太線) と棄却域曲線 (図 2 の破線)に対して, 観測值曲線 (図 2 の細線）を比較することにより，基盤に対する活 動点の分布性状を示すものである。このグラフを用 いて，観測值曲線が期待值曲線より高い場合は凝集 型を，期待值曲線と同じ場合はランダム型を，期待 值曲線より低い場合は均等型（お互いに離れあうよ うな関係）を判断できる。

例えば，図 2 の観測值曲線 $\mathrm{A}$ は母点に比較的近. い領域では均等型を，母点から遠い領域では凝集型 を示す．なお，後述する本ツールでは図 2 にあるよ うな縦方向の点線を表示する。この点線は，ネット ワーク総延長に対する一定の割合（図 2 では $10 \%$ ）

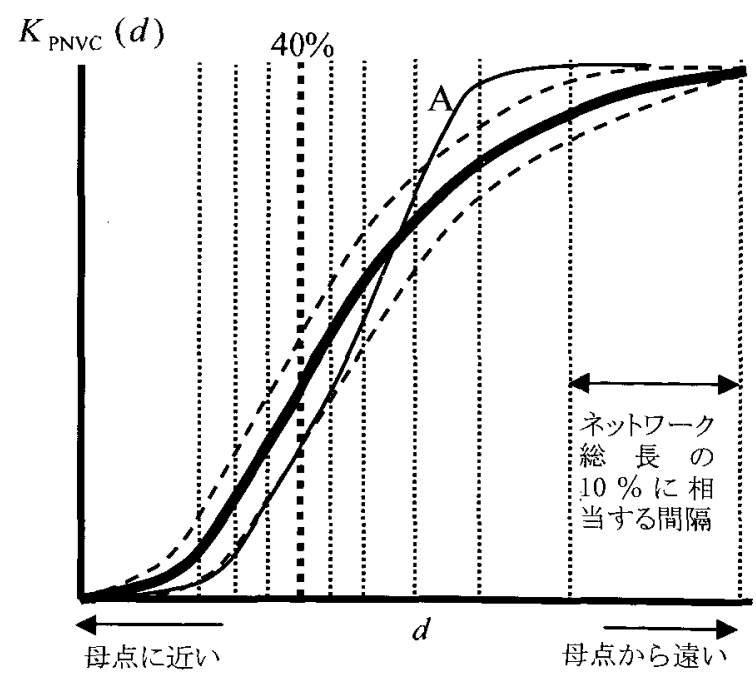

图 2 NVCKF 法のグラフ 
のネットワーク長に相当する圈域ごとに区切るもの である。これは，期待值曲線はネットワークによっ て大きく形状が異なり，母点からの圈域内にどれく らいのネットワーク長があるかがわかりづらいこと から,その目安として表示するものである. 例えば, 図 2 の太点線はネットワーク総延長の $40 \%$ にあた る位置を示し，かなりの範囲で母点に対して有意に 均等型を示していることがわかる。

\section{4. ツールの開発}

以降，本ッールの点 NVCKF 法に対する処理概要 を示す．入力データは，ネットワークデー夕，点的 基盤データ, $n$ 個の点的活動点デー夕（観測点デー 夕），棄却域 $\alpha$ およびネットワーク総延長 $L_{T}$ を等 量に分割するための分割数 $m$ である．また出力は 点 NVCKF 法のグラフである.

なお，二項検定の計算には $\mathrm{R}$ 言語 ${ }^{3)}$ と $\mathrm{R}(\mathrm{D}) \mathrm{COM}^{4)}$ を，ユーザインターフェースには ArcMap Ver.9 を 用いて開発した。 また、ネットワークが一方通行の 場合にも対応している。

Step1 基盤を母点とする NVD を生成する，NVD の生成には最短経路木を求めるダイクスト ラ法を用いた，その際，リンク一本一本の 両端には，生成元からの最短経路距離を格 納しておく，なお，一方通行情報がある場 合は，これに基づいた NVDを生成する。 また同時にネットワークの総延長 $L_{\mathrm{T}}$ を求め ておく

Step2 図 3 に示すような圈域 $d$ と圈域内に存在 するネットワークの罢積長 $L(d)$ ，つまり $\bar{K}_{\mathrm{PNVC}}(d)$ の関係を求める.

Step3 観測点データの位置からネットワーク上の 最近隣点を探し，この点が存在するリンク の両端点に格納されている基盤からの経路 距離とリンク長を用いて, 最近隣地点に㧈 ける経路距離を求める。この值で昇順にソー トすることにより，観測値曲線を求める.

Step4 $L_{\mathrm{T}}$ を $m$ で除算してネットワーク長の等量間 隔を求める。次にこの等量間隔で距離を增
分していき, $\bar{K}_{\mathrm{PNVC}}(d)$ の逆関数を用いるこ とによって，そのときの経路距離を求める.

Step5 $\mathrm{R}$ 言語の標準関数である qbinom 関数は， $\alpha$, 生起確率 $p(d)=\bar{K}_{\mathrm{PNVC}}(d) / L_{\mathrm{T}}$ および $n$ を変 数として代入することにより，棄却域に対 応する個数を算出できるものである。そこ で本ッールでは図 2 で示すような裹却域曲 線を得るために, 経路距離を細かく増分し ながら，その都度， $p(d)$ をもとめ, $\alpha, p(d)$ および $n$ を qbinomに代入し， $\alpha$ に対応す る個数をもとめる。

Step6 最後に, Step2, Step3, Step4 おうよびStep5 で求まった值を使って， $\mathrm{R}$ 言語による図 2 のようなグラフを作成する.

\section{5. 実データによる解析事例}

本節では, 点 NVCKF 法と線 NVCKF 法の解析事 例をそれぞれ示す。

\section{1. 解析用デー夕}

解析に用いるデー夕は，図 4 に示すような京都駅 近辺から京都御苑の南端近辺までの範囲で，一方通 行（図 4 の青矢印が一方通行）を一部に含むネット ワークデータである，また，基盤としては，交番 （31 地点, 図 4 のの印）と主要道路（図 4 の赤色太 線）を用いる，交番と主要道路は，昭文社の『詳細

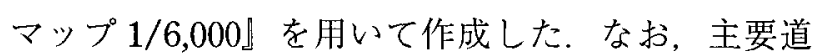
路は,『詳細マップ 1/6,000』に揭載されている路線 名称が載っているものを主要道路と仮定した。また 図 5 は, 図 4 と同じ領域内の車上秝らい(123 地点, 図 5 の赤色ム印）とひったくり（146 地点，図 5 の 青色口印）の発生地点を示し，これらを活動点とみ なして，本手法による解析を行った。ひったりは 京都府警察のホームページ（http://www.pref.kyoto. $\mathrm{jp} /$ fukei/hanjou/index.html, 2005 年 12 月現在)加ら， また車上放らいは，同じく京都府警察のホームペー ジ (http://www. pref.kyoto.jp/fukei/hanjou/index. html, 2006 年 7 月現在) からデータを作成した.

また，有向 NVDでは母点からあるA 地点へ向か う場合と，A 地点から母点へ向かう場合とでは，最 


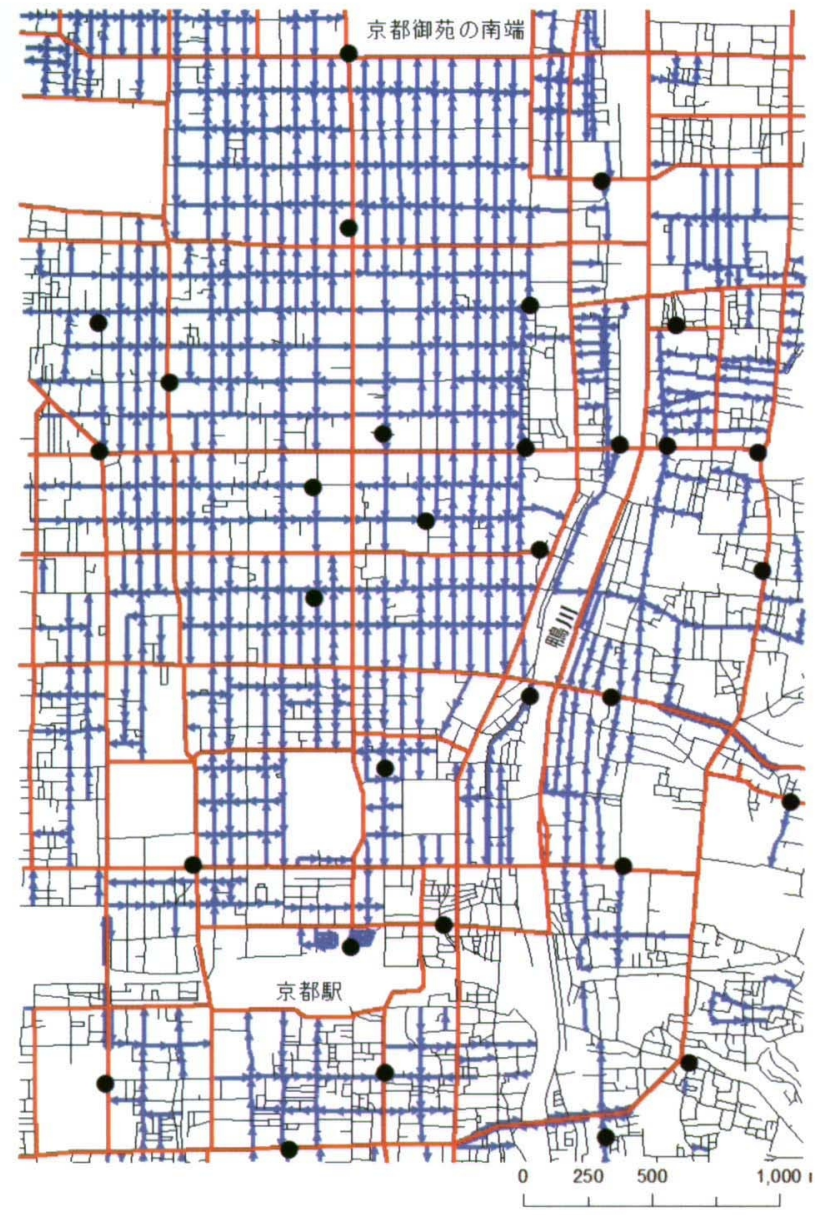

図 4 ネットワークデータと基盤
短経路が異なる場合がある（佐藤・岡部, 2006a). そこで, ここでは有向 NVD の母点または母線へ向 かう方向を「内向き」，母点または母線から外向き に向かう方向を「外向き」と呼ぶこととし，一方通 行を考慮した解析を行う。

なお，犯罪の発生は，時間帯によって大きくこと なることが考えられるが, 今回は, 時間帯に分けて しまうと, 犯罪発生地点の件数が少なくなるため, この件に関しては, 考えないこととした.

\section{2. 点 NCVKF 法を用いた解析事例}

警察庁（2005）では,「空き交番」の問題で，交番 への人員増強のほかに, 交番配置の見直しを行った との報告がある。今後も交番と駐在所の配置見直し は続けるとしているが，こうした計画時には，実際 に交番と犯罪の分布関係を明らかにしたうえで行う ことは重要なことと考える。そこで，交番を基盤と

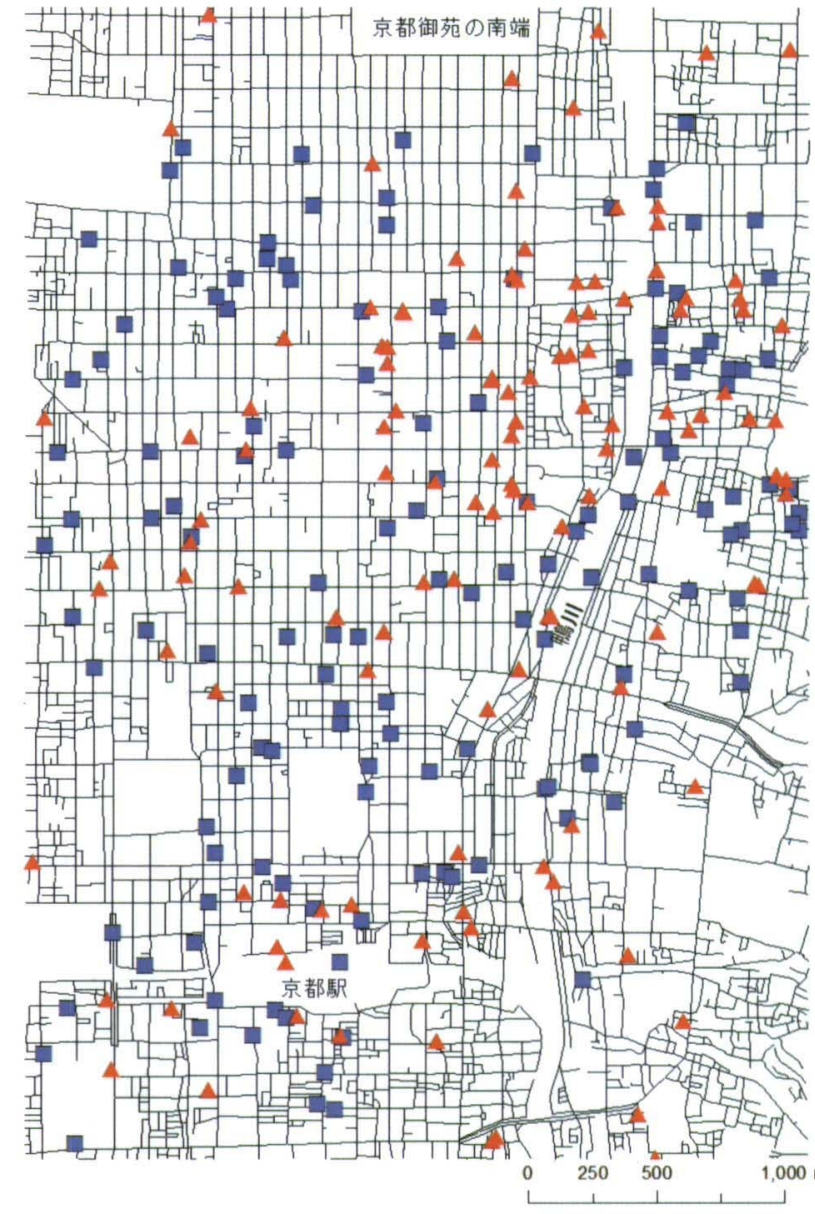

図 5 活動点

し，ひったくりを活動点として，本論文で提案した 手法による解析を行った。 なお，棄却域は $10 \%$ の 両側検定である。またグラフの縦棒の濃い点線は, この点線間の道路長が, 総道路長の $5 \%$ に相当する ことを示している.

交番とひったくりの分布関係は, 図 6-(a) の内向 きの場合，250m（20\%）あたりまではランダム型 を示し, その後, 急激に強い凝集型へ移っていく. 図 6-(b) の外向きの場合は，200m（15\%）までは棄 却域曲線の下限以下となるぐらいの強い均等型を 示し，それ以上から $400 \mathrm{~m}(50 \%)$ ぐらいまでラン ダム型を，それ以上では凝集型を示す。特に $500 \mathrm{~m}$ (60\%) 以上では棄却域曲線を超えて, 強い凝集型を 示す．以上のことから, 交番に対するひったくりは, 一方通行を考慮すると交番から外向きの方向へ，な るべく遠くなるような場所で発生しているといえ る. 


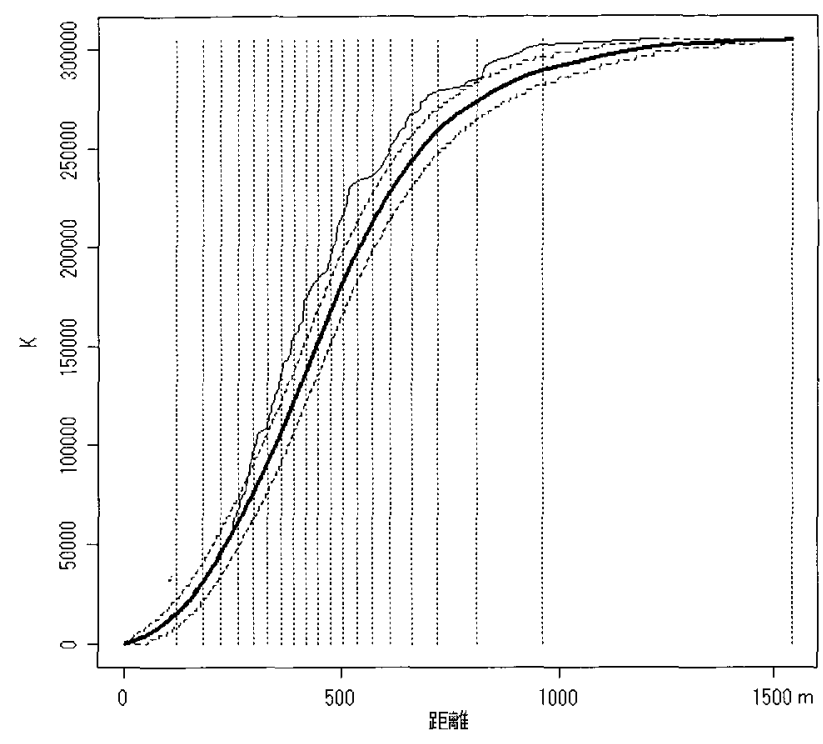

(a) 内向き

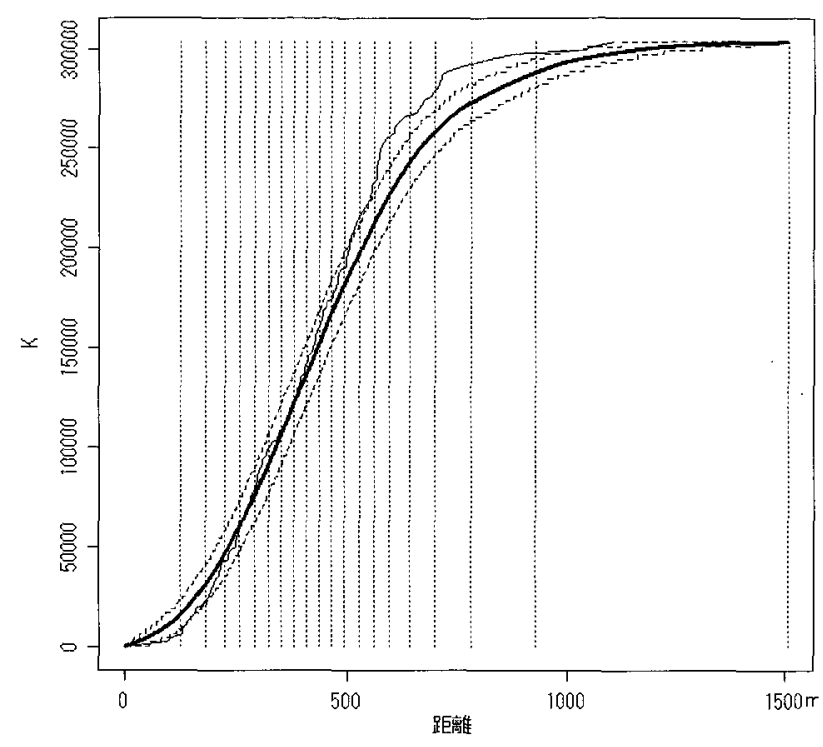

（b）外问き

図 6 交番に対するひったくりの分布

このことから犯罪者が，交番に対して，あまりに 近すぎる $200 \mathrm{~m}$ 圈域内では，犯罪場所として選定し ないのではないかと推測できる。

\section{3．線 NCVKF 法を用いた解析事例}

江口・有馬（2004）は，福岡市をケーススタディ として，犯罪多発地点の特性を調べ，車上ねらいは 主要道路沿いなどで多発していると述べている。し かしこの解析方法は，平面空間におけるカーネル密 度法による定性的な判断によるもので，主要道路か らどれぐらい離れた場所で事件が発生しているかと いう詳細な解析は行われていない，また，佐藤・岡 部（2006b）は，主要道路とひったくり地点の関係 を線ネットワーク最近隣距離法による解析を行い, 主要道路に向かう力向に，ひったくりが凝集する傾 向があることを調べたが，これに関しても，主要道 路からどれぐらい離れた場所で事件が発生している かという詳細な解析は行われていない.

そこで，主要道路に対する車上ねらいとひったく りの分布性状を調べることとする。図 7 は，主要道 路が基盤で，車上ねらい発生地点が活動点とした場 合の線 NVCKF 法の結果を, 罒 8 は, 同じく主要道 路が基盤で，ひったくり発生地点が活動点の場合の 結果を示す。なお，亲却域は $10 \%$ の両側検定であ
る。またグラフの縦棒の濃い点線は，前述と同様で あるが，主要道路がネットワーク総延長に対して約 18.5\%であるため, 図では 20\%からの表示となって いる.

まず活動点が車上衫らいの場合，内向き(図 7-(a)) に関しては，全体的には凝集型を示す．特に50〜 $80 \mathrm{~m}(30 \sim 40 \%)$ 近辺で棄却域曲線を越える強い凝 集型を示すことがわかる．外向き（図 7-(b)）の場合 も，全体的に凝集型の傾向を示すが，150m（60\%） 近辺までは期待値曲線と棄却域曲線のほぼ中央あた りに位置し，180m（70\%）近辺で棄却域曲線を超え るぐらいの凝集型を示していることがわかる.

以上のように，車上齐らいに関しては，その分布 は内向きの場合は全体的に凝集型の傾向を，外向き の場合でも，やや凝集型の傾向を示す。これらのこ とから江口・有馬 (2004) と長澤・細江 (1999)によ る，車上ねらいは主要道路沿いで多く発生し，その 理由としては犯行現場への行きやすさと犯行現場か らの逃走しやすさの両面から主要道路近辺で犯行を 行うのではないか，という結論とほぼ同様な結果を 得たといえる，ただし，その傾向は外向きよりも内 向きの方が顕著に現れており，今回の事例では，車 上ねらいの場合, どちらかというと逃走しやすさを 強く意識しているのではないかと推測できる. 


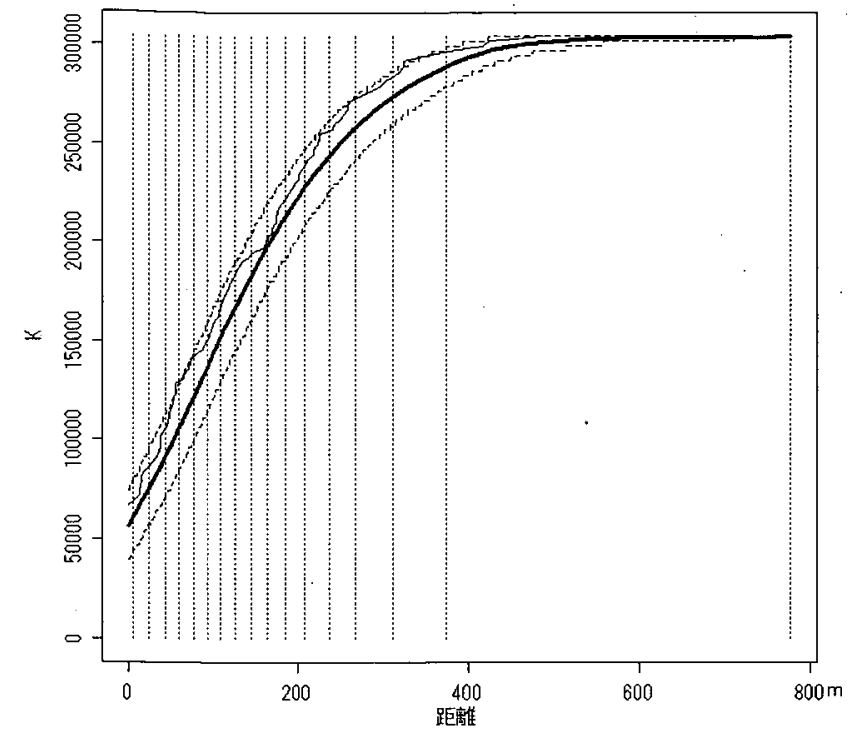

(a) 内向き

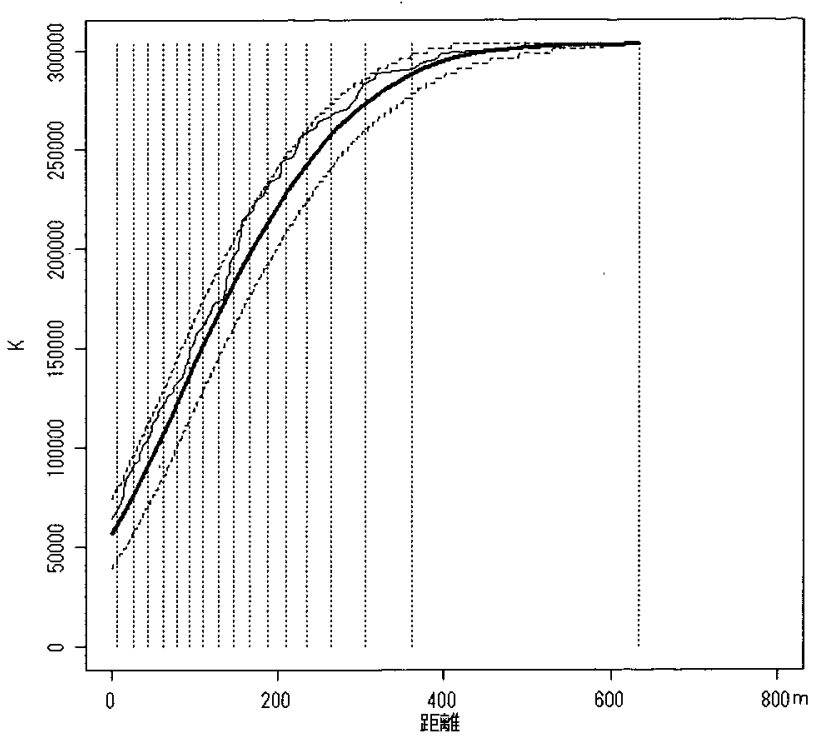

(b) 外向き

図 7 主要道路に対する車上ねらいの分布

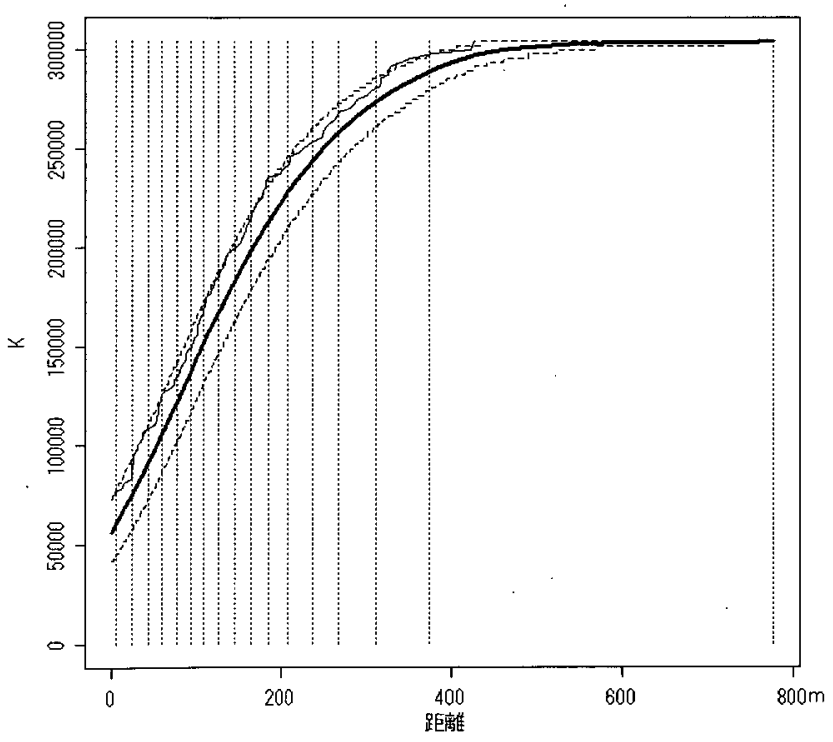

(a) 内向き

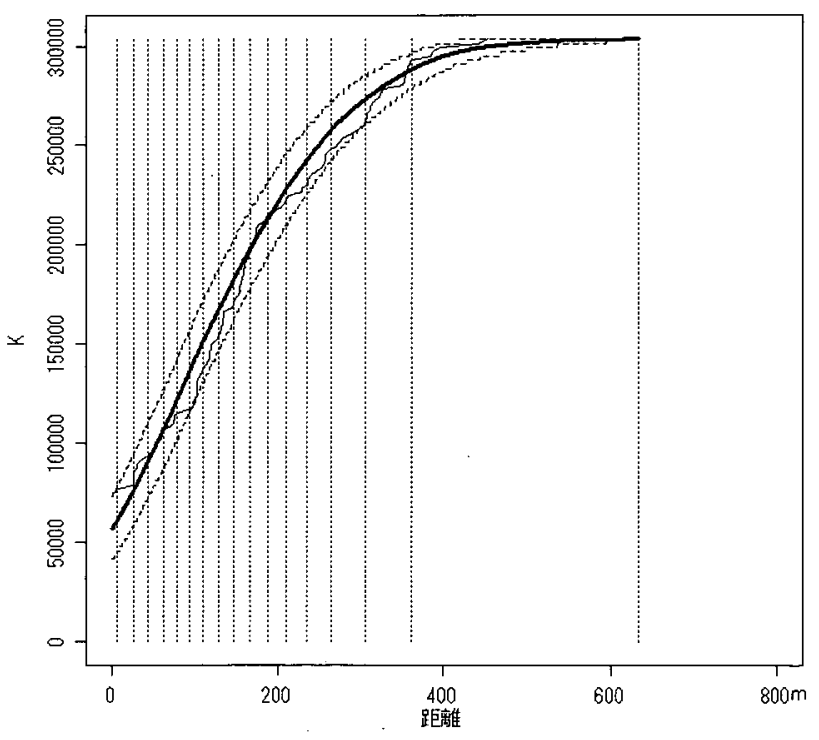

(b) 外向き

図 8 主要道路に対するひったくりの分布

次に，活動点がひったくりで内向き（図 8-(a))の 場合は，全般的に凝集型を示していることがわかる. 外向き（図 8-(b)) の場合は，50m（30\%）付近まで は凝集型を， $80 \mathrm{~m}(40 \%)$ 近辺以上で均等型を示し, $180 \mathrm{~m}(70 \%)$ 付近で, ランダム型の傾向を示すもの の，それ以上では再び均等型の傾向を示し，全般的 に均等型の傾向が見受けられる。

以上のことから，ひったくりに関しては，一方通
行を考虑した場合，主要道路へ向かう側に凝集型の 傾向を,逆に外向きの場合には均等型の傾向を示し， 犯行にはバイクなどが利用されるため道路交通法に 従う必要があり，逃走経路確保を意識して，犯罪場 所の選定を行っているのではないかと推測できる.

以上に示してきた本手法による解析結果は，従来 の手法では得ることができない結果で，新たな知見 を得る可能性があるという意味において，本手法は 
有効であるといえる

\section{6. おわりに}

本論文では，ネットワーク空間上の基盤に対する 活動点の詳細な分布性状を計量的に示すことが可能 な NVCKF 法の提案とそのツールの開発を行った.

また，本ッールを用いて，点 NVCKF 法および線 NVCKF 法の解析事例を示した。点 NVCKF 法では, 基盤として交番を，活動点としてひったくりを対象 とし, 線 NVCKF 法の事例では, 基盤として主要道 路を，活動点として車上ねらいとひったくりを対象 として解析を行った。これらの解析で得られた結果 は，既往の手法では得ることのできなかったもので あり，新たな知見を得る可能性があることから，本 手法の有効性が示された。

今回の解析では，時間带別による解析を行わな かったが，犯罪の発生率は時間帯によって大きく異 なる可能性も考えられるため，今後は，上り多くの デー夕を用いて，継続的な解析を行っていくことが 課題である。

\section{注}

1）高阪宏行氏による「板橋区に抬ける犯罪発生の 空間分析」<http://nihonims.chs.nihon-u.ac.jp/ 板橋犯罪分析 .pdf > (2007 年 10 月現在) 参照.

2）線 NVD とは, 解析対象領域であるネットワー クのサブネットワークを母線とし，その母線と その他のサブネットワークの交差ノードを母点 とみなしたNVDである。ただし，母線上の経 路距離はすべて 0 と仮定する，詳しくは佐藤 · 岡部 (2006b) を参照.

3） $\mathrm{R}$ 言語とは, GNU のもとで開発が進められて いる統計解析ツールである。

4） R(D)COM とは, Microsoft Windows 上の他 のプログラミング言語（例えば, VBAなど）か ら R 言語を制御可能とするコンポーネットで ある. <http://cran.r-project.org/contrib/extra/ dcom/00ReadMe.html>（2007 年 10 月現在）を 参照.

\section{参考文献}

江口聡一郎・有馬隆文 (2004) 空間スケール別に捉えた犯 罪多発地区の特性 一福岡市をケーススタディとし て .「日本建築学会大会学術講演梗概集 (北海道)」, 371-372.

警察庁（2005）警察白書〈平成 17 年版〉特集 : 世界一安 全な道路交通を目指して』，ぎょうせい．

佐藤俊明・岡部篤行 (2006a) 一方通行を含むネットワー クボロノイダイアグラム生成ッールの開発.「GIS 理論と応用」, 14 (1), 1-8.

佐藤俊明・岡部篤行 (2006b) 線および面を生成元とする ネットワークボロノイ図を用いた解析ツールの開発. 「GIS 一 理論と応用」, 14 (2)，53-62.

長澤秀俊・細江達郎 (1999) 車上ねらいの事例を用いた犯 罪発生場所の基礎的研究.「岩手県立大学社会福祉学 部紀要」, 創刊号, 61-72.

Clark, P.J. and Evans, F.C. (1954) Distance to nearest neighbor as a measure of spatial relationships in populations. Ecology, 35, 445-453.

Ripley, B. D. (1981) Spatial Statistics. New York: Wiley.

Okabe, A., Boots, B. and Satoh, T. (2006) A class of local and global K-functions and cross K-functions, AAG Annual Meeting in Chicago, March 2006.

Okabe, A. and Miki, F. (1984) A conditional nearest neighbor spatial association measure for the analysis of conditional location interdependence, Environment and Planning A, 16,163-171. 